\title{
Poczucie tożsamości oraz funkcjonowanie w wymiarze społecznym studentów pochodzących z Białorusi, Ukrainy i Rosji studiujących na polskich uczelniach
}

Streszczenie: Coraz więcej studentów z Europy Wschodniej studiuje w polskich uczelniach. Polska jest dla nich krajem bliskim kulturowo, w którym mogą zdobyć dyplomy uznawane w Europie przy niskich kosztach utrzymania. Wymiar tożsamościowy jest niezwykle ważny, wręcz kluczowy, warunkuje bowiem pojawienie się postaw otwartości lub zamknięcia się na kulturę przyjmującą i replikację tejże postawy wobec języka kraju gospodarza, aktywności na rynku pracy i gotowości wchodzenia w grupy wtórne w społeczeństwie przyjmującym. Przeprowadzone badania wykazały, ze studenci z Białorusi, Ukrainy i Rosji chcą integrować się z polskim społeczeństwem, pozostają jednak bierni i rzadko włączają się życie społeczne uczelni i środowiska lokalnego, nie promują też swojej kultury ojczystej. Społeczeństwo polskie nie jest bowiem otwarte na Innego. W grupie badanej zaobserwowano częste wskazania na uczucie przygnębienia, jakie towarzyszy studentom podczas pobytu w Polsce - jest to spowodowane niewydolnością systemu administracji państwowej, która odpowiada za legalizację pobytu cudzoziemców w Polsce. Postuluje się potrzebę stworzenia stanowisk uczelnianych i wydziałowych koordynatorów do spraw studentów cudzoziemskich, którzy pomagaliby w adaptacji i funkcjonowaniu tych studentów w uczelni i środowisku lokalnym. Za zasadne uznaje się wprowadzenie wolontariackiej instytucji studenta opiekuna, który pomagałby nowo przyjętym studentom w pierwszych miesiącach studiów (kulturowo, językowo i społecznie).

Słowa kluczowe: tożsamość, aktywność społeczna, internacjonalizacja szkolnictwa wyższego w Polsce, wsparcie społeczne, koordynator do spraw studentów cudzoziemskich, Białoruś, Ukraina, Rosja

\section{Wprowadzenie}

Polska staje się coraz bardziej atrakcyjnym kierunkiem migracji edukacyjnej dla młodzieży pochodzącej z państw byłego ZSRR. Trend ten dotyczy zarówno szkolnictwa na poziomie średnim (głównie województwa przygraniczne we 
wschodniej części kraju) oraz szkolnictwa wyższego. Jednym z najważniejszych czynników warunkujących wybór Polski jako kraju nauki czy studiów są: międzynarodowa uznawalność wykształcenia zdobytego w Polsce (dzięki akcesji do UE), stosunkowo niskie bezrobocie oraz koszty utrzymania niższe niż Europie Zachodniej i innych państwach regionu. Obok czynników stricte ekonomicznych ważne są również te o podłożu językowym i kulturowym - Polska jest krajem słowiańskim - a więc krajem o podobnej kulturze i języku, który pod względem liczby użytkowników jest największym językiem zachodniosłowiańskim. Nasza historia po II wojnie światowej to wspólne doświadczenie komunizmu, a potem w latach 90. XX wieku przemian społeczno-politycznych i ekonomicznych. Wreszcie - Polska, jak i inne kraje słowiańskie w Europie Środkowej - z klasycznych państw imigranckich zaczęły przeobrażać się w atrakcyjne strefy emigracyjne (Castels, 2011) i są postrzegane przez naszych braci z Europy Wschodniej, jako kraje należące do Europy Zachodniej, przy jednoczesnym zachowaniu wspomnianych wyżej czynników o podłożu językowym, kulturowym i historycznym. Specyfiką właściwą Polsce jest też spora Polonia zamieszkująca kraje byłego ZSRR, to właśnie polityka zachęcania do podjęcia studiów w Polsce wobec osób polskiego pochodzenia wyznaczyła paradygmat w zakresie rozwiązań prawnych (Karta Polaka) oraz promocyjnych na rzecz umiędzynarodowienia szkolnictwa wyższego w naszym kraju. Trend w napływie do Polski studentów z Europy Wschodniej uległ zdecydowanemu nasileniu od początku drugiej dekady XXI wieku, kiedy to wielu młodych Białorusinów, Ukraińców i Rosjan zdecydowało się podjąć studia w polskich uczelniach niepublicznych (Gomółka, 2017). W roku akademickim 2016/2017 w polskich uczelniach studiowało 65096 tys. studentów cudzoziemskich: 34834 tys. Ukraińców, którzy stanowią obecnie 53,5\% ogółu obcokrajowców w polskich uczelniach, 5188 tys. Białorusinów - stanowią obecnie 7,9\% ogółu studentów obcokrajowców oraz 1028 Rosjan, którzy stanowili 1,57\% ogółu studentów cudzoziemskich w Polsce (Study in Poland: Studenci zagraniczni w Polsce 2017, s. 40).

\section{Tożsamość i aktywność społeczna w kontekście migracji}

Tożsamość buduje się na uznaniu pewnego systemu wartości, które stanowią istotną część dla danej sfery życia społecznego. Wywodzi się ona z wiedzy na temat własnej grupy, jej historii, roli i powołania. Tożsamość zespolona jest także z elementem samooceny budowanej w kontakcie z inną kulturą, akceptacją własnych norm i wartości (Grabowska, 2013, s. 265). Związana jest ze 
zmianami w poczuciu tożsamości narodowej. W wymiarze tożsamościowym można wyróżnić aspekty: poznawczy, behawioralny emocjonalny, które Paweł Boski określa mianem akulturacji psychologicznej (Boski, 2009). Aspekt poznawczy łączy się ze znajomością historii i tradycji. Wiele krajów - w tym również Polska - przy staraniach o obywatelstwo stawia wymóg znajomości nie tylko języka, ale także historii i kultury. Aspekt emocjonalny będzie powiązany $\mathrm{z}$ deklaracjami co do przynależności narodowej. Aspekt behawioralny przejawia się w rozmaitych inicjatywach podejmowanych na rzecz funkcjonowania danej grupy narodowej na przykład Dni Kultury Polskiej w Ufie organizowane przez Stowarzyszenie Polaków w Republice Baszkirii (Rosja).

Emigranci często doświadczają stanu zawieszenia, wynika on z niepewności dotyczącej tożsamości granicznej, kiedy nie wykształciły się jeszcze mechanizmy lojalności i poczucia solidarności z nowym środowiskiem społecznym, a stare związane $\mathrm{z}$ krajem rodzinnym uległy hibernacji lub zostały przerwane (Budyta-Budzyńska, 2011, s. 56). Trzeba jednak zaznaczyć, że dzisiaj dzięki wszechobecności Internetu pełne zerwanie więzi z krajem rodzinnym jest praktycznie niemożliwe (chyba że jest to zamierzona i przemyślana postawa).

Emigrant może przyjąć wobec społeczeństwa przyjmującego następujące postawy:

- utrwalenie tożsamości emigranckiej, czyli poczucia wyobcowania w społeczeństwie przyjmującym i silnego podkreślania swojej tożsamości narodowej;

- poczucia zagubienia, lęku i stresu związanego z poczuciem niepewności o własną tożsamość. W skrajnych przypadkach może wywołać depresję;

- pojawienia się lojalności wobec państwa gospodarza, poczucia solidarności ze społeczeństwem przyjmującym i chęć uczestniczenia w życiu społecznym i politycznym. Niekiedy ujawnia się tzw. tożsamość kreskowa, inaczej zwana też sytuacyjną;

- całkowitego odrzucenia starej tożsamości (asymilacja identyfikacyjna) i przejęcia tożsamości narodowej grupy większościowej (wiąże się to często z silną potrzebą demonstrowania nowej tożsamości).

Wymiar tożsamościowy jest niezwykle ważny. Bez odpowiedzi na pytanie „kim jestem” człowiek nie jest w stanie w pełni funkcjonować w społeczeństwie, a poszukiwanie tożsamości jest najbardziej trwałym i zarazem najtrudniejszym zadaniem w rozwoju człowieka (Grabowska, 2013).

M. Budyta-Budzyńska porównuje tożsamość na emigracji do tej na pograniczu narodowościowym - jest ona wyborem i zależy zarówno od polity- 
ki imigracyjnej państwa przyjmującego oraz polityki emigracyjnej ojczyzny. Tożsamość narodowa na emigracji może się zmieniać wielokrotnie w ciągu życia i mieć charakter płynny (2013, s. 56).

Aktywnością społeczną można nazwać funkcjonowanie migranta w nowym środowisku społecznym oraz sposób, w jaki korzysta z imigranckich sieci społecznych (osobiście, za pomocą mediów społecznościowych). Warto pamiętać, że imigranckie sieci społeczne mogą z jednej strony pomagać imigrantowi w odnalezieniu się w nowej rzeczywistości, z drugiej zaś mogą utrudniać integrację ze społeczeństwem przyjmującym, blokując poznawanie kultury i języka, co w efekcie może doprowadzić do uniemożliwienia awansu społecznego. Wymiar ten wiąże się z wchodzeniem przez emigranta do grup pierwotnych i wtórnych w społeczeństwie gospodarzy i przejmowaniem istniejących ról społecznych (Budyta-Budzyńska, 2011). Bardzo ważna jest postawa społeczeństwa przyjmującego, jego otwartość na Innego, czyli kompetencje międzykulturowe w skali makrospołecznej. Działalność społeczna jest bowiem dialogiem pomiędzy poszczególnymi grupami społecznymi.

\section{Metodologiczne podstawy badań własnych}

Przedmiotem przeprowadzonych badań (Matusiak, 2018) było funkcjonowanie w płaszczyźnie tożsamościowej i społecznej studentów pochodzących z Białorusi, Ukrainy i Rosji, którzy podjęli studia w Polsce. Natomiast celem było poznanie postaw wobec kultury rodzimej i polskiej oraz podejmowanej aktywności społecznej i promowania własnej kultury podczas pobytu w Polsce.

Badania ankietowe zostały przeprowadzone w formie online. Wybrałem tę formę, aby dotrzeć do jak największej liczby osób. Dane zebrano w kwietniu i maju 2018 roku przy pomocy formularza ankiety przepisanego do Formularzy Google, umożliwiających zbieranie danych w sposób zautomatyzowany. Próba badawcza obejmowała 150 osób, byli to studenci pochodzący z Białorusi (51 osób), Rosji (15 osób) i Ukrainy (84 osoby), studiujący w polskich uczelniach. Prośbę o udział w badaniach wraz $\mathrm{z}$ ankietą umieściłem między innymi na portalach społecznościowych Facebook i V Kontakte, w grupach zrzeszających Białorusinów, Rosjan i Ukraińców przebywających w Polsce. O pomoc w rozesłaniu ankiet i dotarcie do studentów poprosiłem również szkoły języka i kultury polskiej, które działają przy uczelniach wyższych w całej Polsce i zajmują się kształceniem językowo-kulturowym studentów cudzoziemskich. W badaniach zastosowano też metodę obserwacji etnograficznej (Rubacha, 
2008) (nazywaną przez innych metodologów obserwacją uczestniczącą), ponieważ w roku 2017 i 2018 wielokrotnie hospitowałem i prowadziłem kursy z języka i kultury polskiej dla studentów pochodzących z Europy Wschodniej, które organizowane były przez Szkołę Języka i Kultury Polskiej UŚ.

\section{Poczucie tożsamości oraz funkcjonowanie w wymiarze społecznym studentów pochodzących z Białorusi, Ukrainy i Rosji studiujących w polskich uczelniach - omówienie wyników badań}

Rozpoczęcie studiów jest ważnym momentem w życiu każdego człowieka; w sytuacji migracyjnej ma on szczególne nacechowanie transgresyjne. Wiąże się nie tylko $\mathrm{z}$ wejściem w inny model kształcenia i zdobywania wiedzy od tego, który znany był jednostce na poprzednich etapach edukacyjnych, ale może przede wszystkim związany jest z poznawaniem i funkcjonowaniem w nowej, innej kulturze in vivo. Wejściu w nową kulturę towarzyszy szok kulturowy, można go jednak zminimalizować przygotowując się wcześniej niejako in vitro - poprzez naukę języka i kultury kraju, do którego się wyjeżdża. Jak wspomniano we wstępie, Polska jest dla studentów z państw Europy Wschodniej krajem bliskim kulturowo i językowo, należy jednak pamiętać, że kraj i kultura, chociażby najbliższe w sensie kulturowym, nie będą nigdy kopią kraju ojczystego. W językach i kulturach pokrewnych występują często tak zwani false friends (fałszywi przyjaciele), czyli zwroty językowe bądź zachowania kulturowe podobne pod względem formy do tych w kulturze ojczystej, ale mające zupełnie inną treść semantyczną.

Dane w tabeli 1 pozwalają zauważyć, że respondenci zdecydowanie nie czują się w Polsce wyobcowani. Potwierdzają to również obserwacje ukraińskich i białoruskich działaczy społecznych, pracujących na rzecz swoich mniejszości narodowych w Polsce. Zdaniem Nedima Usienowa z Fundacji Solidarności Międzynarodowej, „względna bliskość kulturowa i podobieństwo języków sprawiają, że Ukraińcy w Polsce nie zamykają się w gettach. Przeciwnie, szybko integrują się i wtapiają w tłum. Ale próbują też trzymać się razem (Usienow, 2018). Najwięcej odpowiedzi wskazujących na poczucie wyobcowania pojawiło się wśród studentów z Białorusi, najmniej wyobcowani czują się studenci ukraińscy. Ukraina jest bliska Polsce nie tylko geograficznie i kulturowo, ale także z punktu widzenia języka, bowiem język ukraiński - mimo przynależności do wschodniosłowiańskiej grupy językowej - w toku swojego rozwoju zapożyczył z polszczyzny sporo leksyki. 
Tabela 1. Poczucie wyobcowania w Polsce

\begin{tabular}{|l|c|c|c|c|}
\hline \multirow{2}{*}{ Kraj pochodzenia } & \multicolumn{4}{|c|}{ Odpowiedzi w \% } \\
\cline { 2 - 5 } & nie, nigdy & tak, ale rzadko & tak, często & tak, zawsze \\
\hline Białoruś $\mathrm{N}=51$ & 31 & 49 & 16 & 4 \\
\hline Ukraina N=83 & 28 & 59 & 13 & 1 \\
\hline Rosja N=15 & 53 & 33 & 7 & 7 \\
\hline$\sum=149$ & 32 & 52 & 13 & 3 \\
\hline
\end{tabular}

Źródło: badania własne.

Trzeba zaznaczyć, że czasami polityka samych uczelni nie przyczynia się do dobrego stanu psychicznego u studentów zagranicznych w Polsce. Zdarzają się przypadki, że w domach studenckich studentom przydziela się pokoje według ich narodowości - takie praktyki nie są udziałem uczelni z małych ośrodków akademickich, a Uniwersytetu Warszawskiego (Triasun Karpieszuk, 2018).

Tabela 2. Częstsze oglądanie rodzimej kinematografii, słuchanie rodzimych wykonawców podczas pobytu w Polsce

\begin{tabular}{|l|c|c|}
\hline \multirow{2}{*}{\multicolumn{1}{|c|}{ Kraj pochodzenia }} & \multicolumn{2}{|c|}{ Odpowiedzi w \% } \\
\cline { 2 - 3 } & nie & tak \\
\hline Białoruś $\mathrm{N}=51$ & 51 & 49 \\
\hline Ukraina $\mathrm{N}=84$ & 64 & 36 \\
\hline Rosja $\mathrm{N}=15$ & 53 & 47 \\
\hline$\sum=150$ & 59 & 41 \\
\hline
\end{tabular}

Źródło: badania własne.

Dane w tabeli 2 pozwalają zauważyć, że respondenci nie oglądają rodzimych filmów i nie słuchają rodzimych wykonawców częściej niż przed przyjazdem do Polski. Należy zaznaczyć, że wynik ten jest skorelowany z bardzo niskim stopniem poczuciem wyobcowania w Polsce. Za rodzimą kinematografią tęsknią najbardziej studenci z Białorusi.

Tabela 3. Odczuwanie lęku i przygnębienia spowodowanego pobytem w Polsce

\begin{tabular}{|l|c|c|c|c|c|}
\hline \multirow{2}{*}{$\begin{array}{c}\text { Kraj } \\
\text { pochodzenia }\end{array}$} & \multicolumn{5}{|c|}{ Odpowiedzi w \% } \\
\cline { 2 - 6 } & nie, nigdy & $\begin{array}{c}\text { tak, ale } \\
\text { rzadko }\end{array}$ & tak, czasem & tak, często & $\begin{array}{c}\text { tak, te uczucia towarzyszą } \\
\text { mi od początku mojego } \\
\text { pobytu w Polsce }\end{array}$ \\
\hline Białoruś N=50 & 54 & 34 & 6 & 4 & 2 \\
\hline Ukraina N=84 & 52 & 26 & 15 & 5 & 1 \\
\hline Rosja N=15 & 73 & 7 & 13 & 0 & 7 \\
\hline$\sum=149$ & 55 & 27 & 12 & 4 & 2 \\
\hline
\end{tabular}

Źródło: badania własne. 
Większość studentów nie odczuwa lęku i przygnębienia spowodowanego pobytem w Polsce. Przyczyny tego stanu rzeczy można upatrywać w tanich i dostępnych połączeniach internetowych, które umożliwiają stały kontakt z rodziną - należy bowiem pamiętać, że abiturienci z badanych krajów otrzymują świadectwo dojrzałości w wieku 17 lat i zazwyczaj w takim wieku przyjeżdżają do Polski. Analiza danych w tabeli 1 potwierdza wzajemną korelację małego poczucia wyobcowania w Polsce (tabela 3) z dobrostanem psychicznym respondentów. Na zajęciach z języka polskiego jako obcego, na których poruszane są tematy realioznawcze (zezwolenie na pobyt etc.), studenci często podkreślali, że procedury związane z legalizacją pobytu są bardzo długie, a to wiąże się z poczuciem niepewności i stresu. Dane w tabeli 3 pozwalają zauważyć, że przygnębienie podczas pobytu w Polsce najczęściej odczuwają studenci rosyjscy, dla nich bowiem procedura pobytowa poza granicami Polski wiąże się z długą i kosztowną podróżą do domu (wyrobienie nowej wizy w jednym z konsulatów RP na terenie Federacji Rosyjskiej), dlatego najczęściej składają wnioski o wydanie karty pobytu w Polsce (urząd wojewódzki właściwy dla miejsca zamieszkania), a procedura ta trwa obecnie ponad rok. Jeśli decyzja jest odmowna, muszą opuścić Polskę.

Studentów w badanej grupie zapytano o odczuwanie solidarności ze społeczeństwem polskim - na przykład podczas rozgrywek sportowych, wydarzeń społecznych (protestów) etc.

Tabela 4. Poczucie solidarności z polskim społeczeństwem

\begin{tabular}{|l|c|c|c|c|c|}
\hline \multirow{2}{*}{$\begin{array}{c}\text { Kraj } \\
\text { pochodzenia }\end{array}$} & \multicolumn{5}{|c|}{ Odpowiedzi w \% } \\
\cline { 2 - 6 } & nie, nigdy & $\begin{array}{c}\text { tak, ale } \\
\text { rzadko }\end{array}$ & tak, czasem & tak, często & $\begin{array}{c}\text { tak, zawsze mam poczucie } \\
\text { solidarności ze społeczeń- } \\
\text { stwem polskim }\end{array}$ \\
\hline Białoruś N=50 & 4 & 10 & 26 & 30 & 30 \\
\hline Ukraina N=83 & 8 & 11 & 12 & 47 & 22 \\
\hline Rosja N=15 & 7 & 13 & 20 & 47 & 13 \\
\hline$\sum=148$ & 7 & 11 & 18 & 41 & 24 \\
\hline
\end{tabular}

Źródło: badania własne.

Dane w tabeli 4 pozwalają zauważyć, że większość respondentów często i bardzo często odczuwa solidarność ze społeczeństwem polskim.

W tabeli 5 Przedstawiono stosunek osób badanych do języka i kultury ojczystej. 
Tabela 5. Stosunek do języka i kultury ojczystej

\begin{tabular}{|l|c|c|c|c|}
\hline \multirow{2}{*}{$\begin{array}{c}\text { Kraj } \\
\text { pochodzenia }\end{array}$} & $\begin{array}{c}\text { Odecydowanie nie } \\
\text { stanowią dla mnie } \\
\text { wartości }\end{array}$ & $\begin{array}{c}\text { Oaczej nie stanowią } \\
\text { dla mnie wartości }\end{array}$ & $\begin{array}{c}\text { raczej stanowią dla } \\
\text { mnie wartość }\end{array}$ & $\begin{array}{c}\text { zdecydowanie } \\
\text { stanowią dla mnie } \\
\text { wartość }\end{array}$ \\
\hline Białoruś N=49 & 0 & 10 & 29 & 61 \\
\hline Ukraina N=83 & 1 & 7 & 31 & 61 \\
\hline Rosja N=15 & 0 & 20 & 27 & 53 \\
\hline$\sum=147$ & 1 & 10 & 29 & 60 \\
\hline
\end{tabular}

Źródło: badania własne.

Zdaniem Władysława Miodunki pozytywny stosunek do języka i kultury ojczystej determinuje aktywną postawę w nauce innych języków obcych i przyśpiesza proces akwizycji językowej (Miodunka, 2016). Warto zaznaczyć, że największy udział narodowościowy w grupie badanej stanowili Ukraińcy, a obecnie w Ukrainie język i kultura narodowa są mocno wspierane i promowane przez władze państwowe, aby jak najbardziej zminimalizować znaczenie języka rosyjskiego. Dla większości studentów z Białorusi język i kultura narodowa też stanowią wartość; trzeba zaznaczyć, że obecnie wśród młodych Białorusinów wzrasta świadomość odrębności językowej i kulturowej - coraz częściej mówią po białorusku, a nie w języku Puszkina (pomimo unii gospodarczej z Rosją). Zauważalną tendencją jest systematyczne ograniczanie znaczenia języka rosyjskiego w państwach byłego ZSRR, np. w Kazachstanie planowane jest zniesienie zapisu języka kazachskiego w cyrylicy.

Tabela 6. Podejmowanie działań na rzecz promowania kultury narodowej w uczelni lub środowisku lokalnym

\begin{tabular}{|l|c|c|c|c|}
\hline \multirow{2}{*}{ Kraj pochodzenia } & \multicolumn{4}{|c|}{ Odpowiedzi w \% } \\
\cline { 2 - 5 } & nie, nigdy & tak, rzadko & tak, często & tak, bardzo często \\
\hline Białoruś $\mathrm{N}=51$ & 59 & 33 & 6 & 2 \\
\hline Ukraina N=82 & 56 & 33 & 9 & 2 \\
\hline Rosja N=15 & 53 & 27 & 20 & 0 \\
\hline$\sum=148$ & 57 & 32 & 9 & 2 \\
\hline
\end{tabular}

Źródło: badania własne.

Działalność społeczna pro publico bono podejmowana jest przez jednostki lub grupy wtedy, gdy człowiek potrafi zaspokoić swoje podstawowe potrzeby, wiąże się to między innymi z pozytywnym przebiegiem procesu kulturalizacji oraz przyjęcia strategii integracji wobec społeczeństwa przyjmującego. Respondentów zapytano, czy podejmują działania na rzecz promowania swojej 
kultury narodowej w środowisku lokalnym. Częstości poszczególnych odpowiedzi przedstawiono w tabeli 6.

Dane w tabeli 6 pozwalają zauważyć, że respondenci rzadko podejmują działania na rzecz promowania swojej kultury w środowisku akademickim i lokalnym, mimo deklaracji, że dla większości z nich (59,3\%) język i kultura narodowa stanowią wartość. $Z$ badań na temat zaangażowania społecznego Ukraińców w Polsce (wywiady pogłębione) przeprowadzonych przez Andriya Kornichuka i Łukasza Wenerskiego (Kornichuk, Wenerski, 2016) dowiadujemy się, że za najważniejsze ośrodki miejskie w Polsce, w których społeczność ${ }^{1}$ ukraińska aktywnie promuje własną kulturę, można uznać Warszawę, Gdańsk i Olsztyn. W miastach tych działają fundacje na rzecz migrantów z Ukrainy, które są widoczne w kulturalnej tkance miejskiej. Badacze wskazują również na aktywną postawę duchownych grekokatolickich w promowaniu kultury ukraińskiej. Natomiast miastami, które przyciągają najwięcej ukraińskich studentów, są: Warszawa, Kraków, Lublin, Wrocław i Katowice. Najwięcej działań na rzecz promowania swojej kultury narodowej podejmują studenci z Rosji - jest to w mojej opinii związane ze studiami rusycystycznymi, które wielu Rosjan podejmuje w Polsce, a to wiąże się z działalnością na rzecz kultury i języka ojczystego (w grupie studentów, którzy uczęszczali na hospitowane przeze mnie zajęcia z języka polskiego dla obcokrajowców, wszyscy studenci z Rosji studiowali rusycystykę).

Badanych studentów zapytano o zaangażowanie w życie społeczne uczelni, w których studiują. Odpowiedzi przedstawiono w tabeli 7. Najbardziej aktywnymi członkami społeczności akademickiej w grupie badanej okazali się studenci z Ukrainy, zaś najmniej aktywni byli Rosjanie.

Tabela 7. Zaangażowanie w życie społeczne uczelni

\begin{tabular}{|l|c|c|}
\hline \multirow{2}{*}{\multicolumn{1}{|c|}{ Kraj pochodzenia }} & \multicolumn{2}{|c|}{ Odpowiedzi w \% } \\
\cline { 2 - 3 } & nie & tak \\
\hline Białoruś $\mathrm{N}=50$ & 70 & 30 \\
\hline Ukraina $\mathrm{N}=82$ & 67 & 33 \\
\hline Rosja $\mathrm{N}=14$ & 71 & 29 \\
\hline$\sum=146$ & 68 & 32 \\
\hline
\end{tabular}

Źródło: badania własne.

1 Celowo nie użyłem sformułowania „mniejszość”, ponieważ chcę oddać działalność migrantów ukraińskich, a nie mniejszości narodowej, która mieszka na ziemiach polskich od wielu pokoleń. 
Dane w tabeli 7 pozwalają zauważyć, że studenci z Białorusi Federacji Rosyjskiej i Ukrainy, którzy studiują w polskich uczelniach, przyjmują strategię pasywną i niechętnie włączają się w życie społeczne uczelni. Respondenci, którzy angażują się w życie społeczne uczelni, wskazywali następujące aktywności (tabela 8).

Tabela 8. Wskazania aktywności studentów angażujących się w życie społeczne uczelni

\begin{tabular}{|l|c|c|c|c|c|c|}
\hline \multirow{2}{*}{$\begin{array}{c}\text { Kraj } \\
\text { pochodzenia }\end{array}$} & \multicolumn{7}{|c|}{ Odpowiedzi w \% } \\
\cline { 2 - 7 } & $\begin{array}{c}\text { Akademicki } \\
\text { Związek } \\
\text { Sportowy }\end{array}$ & $\begin{array}{c}\text { koła } \\
\text { naukowe }\end{array}$ & $\begin{array}{c}\text { Samorząd } \\
\text { Studencki }\end{array}$ & $\begin{array}{c}\text { inne } \\
\text { wydarzenia }\end{array}$ & $\begin{array}{c}\text { Rada } \\
\text { Mieszkańców } \\
\text { w DS }\end{array}$ & $\begin{array}{c}\text { Erasmus } \\
\text { Student } \\
\text { Network }\end{array}$ \\
\hline Białoruś N=15 & 30 & 50 & 10 & 0 & 5 & 5 \\
\hline Ukraina N=25 & 28 & 44 & 22 & 3 & 0 & 3 \\
\hline Rosja N=4 & 25 & 75 & 0 & 0 & 0 & 0 \\
\hline$\sum=44$ & 29 & 47 & 16 & 2 & 2 & 4 \\
\hline
\end{tabular}

Źródło: badania własne.

Dane zawarte w tabeli 8 pozwalają zauważyć, że studenci najchętniej działają w kołach naukowych (63\%) i AZS 34,8\%) należy zaznaczyć, że instytucja kół naukowych i uczelnianych klubów sportowych funkcjonuje w krajach byłego ZSRR, być może znajomość tych instytucji społecznych z własnej kultury zachęca do działania w nich w Polsce.

Badanych zapytano również o zawieranie relacji przyjacielskich z Polakami. Częstości poszczególnych odpowiedzi przedstawiono w tabeli 9.

Tabela 9. Zawieranie relacji koleżeńskich lub przyjacielskich z Polakami

\begin{tabular}{|l|c|c|}
\hline \multirow{2}{*}{\multicolumn{1}{|c|}{ Kraj pochodzenia }} & \multicolumn{2}{|c|}{ Odpowiedzi w \% } \\
\cline { 2 - 3 } & nie & tak \\
\hline Białoruś $\mathrm{N}=51$ & 31 & 69 \\
\hline Ukraina $\mathrm{N}=82$ & 18 & 82 \\
\hline Rosja $\mathrm{N}=15$ & 20 & 80 \\
\hline$\sum=148$ & 23 & 77 \\
\hline
\end{tabular}

Źródło: badania własne.

Dane w tabeli 9 pozwalają zauważyć, że studenci z Białorusi, Federacji Rosyjskiej i Ukrainy studiujący w polskich uczelniach chętnie zawierają znajomości z Polakami (77,3\%). Najchętniej czynią to studenci z Ukrainy, jest to najpewniej powiązane z najmniejszą barierą językową, o której pisałem przy analizie danych z tabeli 1 . 
Respondenci (N=143) wskazali, że liczba ich polskich znajomych i przyjaciół mieści się najczęściej w przedziale od 5 do 10 osób dla 44,4\%, od 10 do 15 dla 20,7\% oraz 15 i więcej dla 34,8\%². Dane te pozwalają przypuszczać, że respondenci chętnie wchodzą w grupy wtórne (uczelnia, praca) w społeczeństwie polskim. Zapewne ważnym czynnikiem sprawczym dla zawierania znajomości między Polakami a respondentami jest bliskość kulturowa i językowa. Osoby pochodzące z Europy Wschodniej stanowią dla Polaków Innego, ale jest to Inny tak zwany bliski (Bogdanowska, 2015), czyli taki, którego łatwiej przychodzi nam oswoić i zrozumieć.

\section{Podsumowanie}

Dobra adaptacja i funkcjonowanie w Polsce byłyby niemożliwe bez pomocy społeczeństwa przyjmującego; w tym wypadku za taką pomoc odpowiadają uczelnie, na które rekrutują się cudzoziemcy. Ważną rolę spełniają tutaj działania w zakresie umożliwienia nauki języka polskiego, poznawania kultury polskiej, ale także włączanie studentów w życie społeczne uczelni i środowiska lokalnego. Istotne jest również stymulowanie kontaktów z polskimi studentami.

Badania wykazały, że w płaszczyźnie społecznej badani przyjęli strategię pasywności na polu działań promocyjnych na rzecz kultury własnej w Polsce i małe zaangażowanie na rzecz życia społecznego uczelni, w których studiują. Być może brak otwartości ze strony Polek i Polaków implikuje małą aktywność na rzecz promowania kultury narodowej przez respondentów. Należy pamiętać, że jeśli studenci z krajów bliskich nam kulturowo niezbyt chętnie chcą pokazywać i promować swoją kulturę, to tym bardziej nie będą czynić tego studenci z kultur nam odległych, a oni coraz częściej patrzą na Polskę, kiedy przyglądają się edukacyjnej mapie Europy. Uczelnie powinny wprowadzić instytucję koordynatorów uczelnianych i wydziałowych do spraw studentów cudzoziemskich, tak jak ma to miejsce na przykład ze studentami niepełnosprawnymi. Koordynatorzy mogliby zachęcać studentów cudzoziemskich do podejmowania działań kulturalnych i społecznych w uczelni i środowisku lokalnym, a także - jak ma to miejsce w uczelniach zachodnich - organizować tak zwane wieczory narodów, w czasie których grupy mniejszościowe mogłyby prezentować swoją kulturę ojczystą na różnych płaszczyznach (język, kuchnia, sztuka) oraz stwarzać przestrzeń do wzajemnego dialogu i poznawania się. Zasadnym wydaje się również wprowadzenie instytucji studenta opiekuna tzw.

2 Badania własne. 
buudy student (jak to ma miejsce w programie Erasmus+), który na zasadzie wolontariatu pomagałby studentowi cudzoziemskiemu w załatwianiu formalności w pierwszych miesiącach studiów, ale też zaznajamiał z polską kulturą i tak zwanym stylem życia. W krajach zachodnich taki student wolontariusz otrzymuje dodatkowe punkty przy staraniu się o stypendia.

\section{Bibliografia}

Castels, S. i Miller, M.J. 2011. Migracje we wspótczesnym świecie. Warszawa: PWN.

Boski, P. 2009. Kulturowe ramy zachowań społecznych: podręcznik psychologii międzykulturowej. Warszawa: PWN.

Bogdanowska-Jakubowska, E. 2015. Inny1 i Inny2 - znaczenie potoczne kontra znaczenie akademickie. W: Bogdanowska-Jakubowska, E. red. Inność/ różnorodność w języku i kulturze. Katowice: UŚ, ss. 9-28.

Budyta-Budzyńska, M. red. 2011. Integracja czy asymilacja? Polscy imigranci w Islandii. Warszawa: „Scholar”.

Budyta-Budzyńska, M. 2013. Socjologia narodu i konfliktów etnicznych. Warszawa: PWN.

Gomółka, K. 2017. Polityka Polski wobec studentów, doktorantów i stażystów z państw poradzieckich. Torun: Wydawnictwo Adam Marszałek.

Grabowska, B. 2013. Poczucie tożsamości młodzieży uczacej się w szkołach z polskim jezzykiem nauczania na Białorusi, Ukrainie i w Republice Czeskiej - studium porównawcze. Toruń: Wydawnictwo Adam Marszałek.

Kornicuk, A. i Wenerski, Ł. 2016. Zaangażowanie społeczno-obywatelskie Ukraińców w Polsce. W: Łada, A. i Böttger, K. red. \#EngagEUkraine. Zaangażowanie społeczne Ukraińców w Polsce i w Niemczech. Warszawa: Fundacja Instytut Spraw Publicznych, ss. 35-85.

Matusiak, Ł. 2018. Strategie funkcjonowania $w$ Polsce studentów z Bialorusi, Federacji Rosyjskiej i Ukrainy. Praca magisterska napisana pod kierunkiem dr hab. B. Grabowskiej, prof. UŚ. Cieszyn: Uniwersytet Śląski, Wydział Etnologii i Nauk o Edukacji.

Miodunka, W. 2016. Glottodydaktyka polonistyczna: pochodzenie - stan obecny - perspektywy. Kraków: Księgarnia Akademicka.

Usienow, N. 2018. Ukraińcy w Polsce: gastarbeiterzy, studenci, przedsiębiorcy, https://forumdialogu.eu/2018/04/23/ukraincy-w-polsce-gastarbeiterzystudenci-przedsiebiorcy/ (3.06.2018). 
Rubacha, K. 2008. Metodologia badań nad edukacją. Warszawa: WAiP. Triansun, Y. i Karpieszuk, W. 2018. Dlaczego zagraniczni studenci nie mieszkaja w akademikach razem $z$ Polakami? http://warszawa.wyborcza.pl/warszawa/7,54420,23321979, dlaczego-zagraniczni-studenci-nie-mieszkaja-w-akademikach-razem.html\#Z_Czolka3Img (4.06.2018).

Study in Poland: Studenci zagraniczni w Polsce 2017. Warszawa: Wydawnictwo Fundacja Edukacyjna „Perspektywy”.

\title{
The feeling of identity and social functioning of students from Belarus, Ukraine and Russia studying in Polish universities
}

\begin{abstract}
More and more students from Eastern Europe study in Polish universities. Poland is a culturally-close country where they can earn diplomas recognized in Europe at low living costs. Studies have shown that students from Belarus, Ukraine and Russia want to integrate with the Polish society, but they remain passive and rarely involve university and local communities and promote their native culture in Poland. The identity dimension is extremely important, even crucial, for it determines openness or closure of the host culture and its replication related to the language of the host country, the activity on the labour market and readiness to join secondary groups in the society of the host country. Studies have shown that students from Belarus, Ukraine and Russia want to integrate with Polish society, however, remain passive and rarely engage in the social life of university and the local environment, do not promote their native culture. Polish society is not open to otherness. In the study group, there were frequent indications of the feeling of depression that accompanies students during their stay in Poland - this is due to the violation of the system of public administration, which is responsible for the legalization of foreigners in Poland. The author postulates the need to create positions at university and departmental coordinators for foreign students, who helped in the adaptation and functioning of these students in the university and the local community. It is considered fundamental to introduce a voluntary educational institution of the student guardian, which would help beginners in the first months of study (cultural, language and social).
\end{abstract}

Keywords: identity, social activity, internationalization of higher education in Poland, social support, coordinator of international students, Belarus, Ukraine, Russia, buddy student 